\title{
Komunikasi Pemasaran dalam Positioning N219 oleh PT Dirgantara Indonesia (Persero)
}

\author{
Yasser Ersyad ${ }^{1}$, Eni Maryani², dan Siti Karlinah ${ }^{3}$ \\ ${ }^{1}$ PT. Dirgantara Indonesia \\ ${ }^{2,3}$ Universitas Padjadjaran
}

\begin{abstract}
ABSTRAK
Tujuan dari penelitian ini adalah untuk mengetahui implementasi komunikasi pemasaran N219 yang berbasis positioning merek. Pendekatan penelitian ini adalah pendekatan kualitatif dengan menggunakan metode studi kasus. Narasumber penelitian ini berjumlah enam orang. Pengumpulan data dilakukan utamanya melalui wawancara mendalam, studi literatur dan observasi. Hasil penelitian menunjukkan bahwa N219 dimaksudkan untuk mengambil pasar Twin Otter yang perlu digantikan baik dari segi teknologi maupun usia dalam melayani penerbangan perintis di Indonesia. N219 diposisikan sebagai pesawat terbang pengganti Twin Otter di Indonesia dengan menggunakan slogan "The New Generation of Light Class Aircraft". Selain itu, N219 juga diposisikan sebagai karya anak bangsa, untuk membentuk manfaat emosional antara merek dengan konsumen potensial serta khalayak luas. Komunikasi pemasaran untuk menyampaikan nilai-nilai positioning dilakukan dengan berbagai sarana, yakni melalui pameran pemasaran, publisitas di media massa, dan pendekatan langsung. Saran penelitian selanjutnya dapat fokus pada bagaimana hubungan proses generatif, produktif, dan representatif yang terjadi dalam penciptaan nilai di sebuah perusahaan. Hubungan ketiganya dapat dijadikan fokus untuk membentuk model yang lebih tepat untuk penggambaran yang lebih universal. Sedangkan saran praktisnya adalah bahwa perlu adanya koordinasi yang lebih baik antara fungsi Humas dan Komunikasi Pemasaran. Di dalam perusahaan, keduanya merupakan alat utama untuk berkomunikasi dengan pihak eksternal perusahaan. Kemudian perlu dieksplorasi sarana-sarana komunikasi pemasaran baru sebagai alternatif kunjungan langsung ke perusahaan-perusahaan dalam pemasaran tatap muka, yang membutuhkan cukup banyak biaya dan waktu. Misalnya, dengan menempatkan lebih banyak perwakilan pemasaran (marketing representative) di daerah-daerah, dan sebagainya.
\end{abstract}

Kata-kata Kunci: Komunikasi pemasaran; pameran; pertukaran nilai; positioning; publisitas

\section{Marketing Communication in N219 Positioning by PT Dirgantara Indonesia (Persero)}

\begin{abstract}
This research aims to determine the implementation of brand-positioning-based marketing communication for N219. This research uses qualitative approach with case study method. This research includes six interviewees, five of them are from PTDI plus one external source. Data collected from in-depth interview, observations and study of literature. The results show that N219 is meant to take Twin Otter market to serve pioneering flights in Indonesia, that is needed to be replaced both age-wise and technology-wise. N219 positioned as Twin Otter replacement in Indonesia using the tagline "The New Generation of Light Class Aircraft." Also, N219 positioned as "a homegrown aircraft", to create emotional benefit between the brand and potential consumers and public audience. Marketing communication conducted to deliver positioning values implemented by several tools, which are marketing shows, mass media publicity, and direct approach. Further research suggestions can focus on how generative, productive, and representative process relationships arise in the creation of a company. The relationship of the three can be the focus of forming a more appropriate model for a more universal portrayal. While the practical advice is that there is a need for better coordination between the PR and Marketing Communications functions. Within the company, those two are tools to communicate with external parties. It needs to be supplemented with new marketing communication tools as an alternative to direct visits to companies in face-to-face marketing, which requires considerable cost and time. For example, by placing more marketing representatives in the regions, and so on.
\end{abstract}

Keywords: Marketing communication; positioning; publicity; trade shows; value exchange

Korespondensi: Yasser Ersyad, S.I.Kom., M.I.Kom. PT. Dirgantara Indonesia Jl. Pajajaran No. 154, Husen Sastranegara, Cicendo, Kota Bandung, Jawa Barat 40174.Email: yassersyad@gmail.com

Submitted: July 2016, Accepted: January 2017, Published: June 2018

ISSN: 2303-2006 (print), ISSN: 2477-5606 (online). Website: http://jurnal.unpad.ac.id/jkk

Terakreditasi Kemenristekdikti RI SK No. 48a/E/KPT/2017 


\section{PENDAHULUAN}

Pesawat N219 dari PT Dirgantara Indonesia (PTDI) merupakan produk baru pesawat bermesin turboprop ganda berkapasitas 19 penumpang yang cocok untuk digunakan untuk penerbangan-penerbangan perintis. Target pasar utama produk ini adalah maskapai-maskapai penerbangan perintis di Indonesia. Tujuannya adalah untuk menjadikan N219 menjadi pilihan terbaik dan utama untuk penerbanganpenerbangan perintis dan berjarak pendek dan menguasai pasar pesawat terbang di kelasnya yang saat ini dikuasai Twin Otter, pesawat terbang produksi Kanada yang pertama kali diluncurkan pada 1965.

Sebagai produk baru di pasar, N219 saat ini masih berada pada fase introduction dalam siklus hidupnya. Kesadaran dan penerimaan khalayak dan konsumen potensial terhadap produk minim, sehingga fokus pemasaran N219 adalah membangun dan mendorong kesadaran dan penerimaan konsumen tersebut. Bagaimana PTDI memperkenalkan N219 pada konsumen dan menetapkan posisi produk tersebut di pasar menjadi hal yang penting.

Pasar pesawat terbang kelas ringan memang bukan pasar yang penuh dengan kompetitor, namun N219 harus memiliki nilai yang membedakannya dari produk-produk pesawat terbang kecil lainnya. Sebab, pada pemasaran yang bersifat business-to-business (B2B) ini manfaat fungsional biasanya menjadi acuan utama dalam keputusan pembelian, sehingga pertambahan nilai pada merek sangat diperlukan untuk memengaruhi pembuatan keputusan tersebut. N219 dibangun berdasarkan kebutuhan pasar di Indonesia, selanjutnya PTDI harus menjadikan N219 sebagai produk yang diinginkan oleh target pasar tersebut.

Nilai merupakan komponen utama dalam pemasaran, karena pemasaran merupakan kegiatan pertukaran nilai antara produsen dengan konsumennya. Dengan pemahaman bahwa kedua pihak bisa jadi pemasar, maka nilai dan manfaat tidak hanya akan dirasakan oleh satu pihak saja namun oleh produsen dan konsumen sekaligus. Sebagai sebuah proposisi nilai, positioning sebuah merek menjadi krusial untuk mendorong terjadinya pertukaran, karena pesan positioning menjadi sebuah penawaran yang diproses oleh konsumen sebagai seperangkat nilai. Keputusan mau atau tidaknya konsumen melakukan pertukaran bergantung pada perangkat nilai yang ditawarkan sebuah produk.

Media promosi adalah semua sarana atau upaya untuk menampilkan pesan atau informasi yang ingin disampaikan oleh komunikator, baik itu melalui media cetak, elektronik (TV, radio, komputer, dll) dan media luar ruang, sehingga sasaran dapat meningkat pengetahuannya yang akhirnya diharapkan dapat berubah perilakunya ke arah positif terhadap kesehatannya (Komala, Novianti, \& Subekti, 2014).

Pada hakikatnya, promosi merupakan suatu bentuk komunikasi pemasaran dan promosi merupakan salah satu faktor penentu keberhasilan suatu program pemasaran. Promosi atau komunikasi pemasaran ini dapat dikatakan mampu memengaruhi uhi kelangsungan hidup suatu perusahaan. Tanpa promosi, konsumen tidak akan mengenal dan atau bahkan mempergunakan produk atau jasa yang ditawarkan suatu perusahaan, baik yang berskala besar, menengah, maupun yang berskala kecil (Isnaini, 2009). Menurut Clow dan Baack, komunikasi pemasaran terintegrasi mengkoordinasikan dan mengintegrasikan semua elemen dari komunikasi pemasaran untuk memaksimalkan komunikasi pada konsumen dengan biaya yang relatif rendah (dalam Limakrisna, 2008).

\section{METODE PENELITIAN}

Metode penelitian ini adalah metode studi kasus. Stake (dalam Hartoyo dan Supriadi, 2015: 3) mengatakan bahwa studi kasus dapat menjawab signifikansi/manfaat sosial penelitian yang ingin dicapai. Metode ini digunakan untuk meneliti fenomena yakni komunikasi pemasaran N219 oleh PTDI yang berbasis pada positioning. Metode ini digunakan agar fenomena dapat dipandang dari berbagai sisi untuk diungkapkan dan dipahami.

Pengumpulan data dilakukan melalui kegiatan wawancara mendalam, studi literatur dan observasi. Wawancara mendalam melibatkan enam narasumber, lima di antaranya berasal dari internal perusahaan PTDI dan satu narasumber eksternal dari media massa sebagai pengamat. Narasumber dipilih berdasarkan kriteria (1) bersedia berpartisipasi dalam penelitian, (2) memiliki wewenang yang lebih besar dalam pengambilan keputusan 
positioning dan komunikasi pemasaran, (3) berada di dalam departemen atau divisi yang memiliki tanggung jawab terhadap aktivitas komunikasi eksternal perusahaan. Analisis data dilakukan berdasarkan metode five-phased cycle dari Yin (2007: 177), yang terdiri dari (1) compiling, (2) disassembling, (3) reassembling, (4) interpreting, dan (5) concluding.

\section{HASIL DAN PEMBAHASAN}

Pesaing PTDI dalam pasar pesawat kelas ringan ini adalah DHC-6 Twin Otter produksi de Havilland dan Viking Air, yang secara karakteristik hampir sama dengan N219 yang dikeluarkan oleh PTDI. Twin Otter saat ini merupakan pemimpin pasar di Indonesia, dengan jumlah pesawat ini yang beroperasi di Indonesia mencapai 89 unit. Twin Otter juga banyak digunakan untuk penerbanganpenerbangan perintis di pasar N219 yakni Asia Tenggara dan Asia Pasifik.

Berdasarkan kajian pasar PTDI dan Lapan terhadap kelas pesawat 10-19 penumpang di Indonesia, Asia Tenggara dan Asia Pasifik, akan terjadi peningkatan kebutuhan pesawat kelas ringan di pasar ini, dikarenakan banyaknya pesawat di kelas ini yang sudah atau akan mencapai usia 30 tahun. Saat ini sudah banyak armada yang berusia lebih dari 25 tahun namun masih layak dioperasikan karena kondisi pesawat yang masih baik. Sedangkan banyak dari pesawat di kelas ini yang sudah tidak diproduksi lagi, atau diproduksi kembali dengan model lama, sehingga menjadi peluang yang potensial bagi N219.

Positioning untuk N219 menjadi penting karena selama ini fokus bisnis PTDI adalah pada pesawat-pesawat untuk keperluan militer. Sehingga, pasar yang biasa mereka hadapi adalah pasar pemerintah (government market). Pesawat N219 ini adalah produk baru yang akan bersaing dengan pemain-pemain lama yang menghidupkan kembali proyek pesawat kelas ringan mereka yang bermodel lama, dan keberhasilannya di pasar akan membuka jalan bagi PTDI untuk mengembangkan model pesawat yang lebih besar nantinya.

Brand positioning mampu memberikan gambaran kepada konsumen mengenai keuntungan dan manfaat merek dibandingkan dengan produk lain di pasarnya, yang mampu memenuhi kebutuhan atau keinginan konsumen (Ghodeswar, 2008: 6). Dengan strategi brand positioning, khalayak dan konsumen potensial dapat mengetahui manfaat yang dapat diperolehnya sebelum menggunakan produk tersebut, dengan berdasar pada pengetahuan

Tabel 1 Perkiraan Jumlah Pesawat Kelas 10-19 Penumpang di Indonesia, Asia Pasifik dan Asia Tenggara yang Aging (>30 tahun)

\begin{tabular}{|c|c|c|c|c|c|c|c|c|c|c|c|c|}
\hline \multirow{4}{*}{ Asia } & \multicolumn{6}{|c|}{ Civil } & \multicolumn{6}{|c|}{ Military \& Civil Government } \\
\hline & \multirow{2}{*}{\multicolumn{2}{|c|}{ Fleet }} & \multicolumn{4}{|c|}{$>30$ yo } & \multirow{2}{*}{\multicolumn{2}{|c|}{ Fleet }} & \multicolumn{4}{|c|}{$>30$ yo } \\
\hline & & & \multicolumn{2}{|c|}{2017} & \multicolumn{2}{|c|}{2022} & & & \multicolumn{2}{|c|}{2017} & \multicolumn{2}{|c|}{2022} \\
\hline & $\mathrm{T}$ & $\mathrm{S}$ & $\mathrm{T}$ & $\mathrm{S}$ & $\mathrm{T}$ & $\mathrm{S}$ & $\mathrm{T}$ & S & $\mathrm{T}$ & S & $\mathrm{T}$ & $\mathrm{S}$ \\
\hline Indonesia & 48 & 59 & 38 & 1 & 42 & 2 & 106 & 23 & 83 & 1 & 93 & 3 \\
\hline Asia Pacific & 180 & 10 & 120 & 1 & 139 & 1 & 264 & 89 & 71 & 5 & 102 & 12 \\
\hline \multirow[t]{3}{*}{ South East Asia } & 20 & 0 & 13 & 0 & 19 & 0 & 108 & 18 & 62 & 0 & 71 & 0 \\
\hline & 248 & 69 & 171 & 2 & 200 & 3 & 478 & 130 & 216 & 6 & 266 & 15 \\
\hline & \multicolumn{2}{|c|}{317} & \multicolumn{2}{|c|}{173} & \multicolumn{2}{|c|}{203} & \multicolumn{2}{|c|}{608} & \multicolumn{2}{|c|}{222} & \multicolumn{2}{|c|}{281} \\
\hline $\mathrm{T}=$ Twin engine & \multicolumn{6}{|c|}{$\mathrm{S}=$ Single engine } & & & & & & \\
\hline
\end{tabular}


yang sudah mereka miliki sebelumnya dengan produk pesaing.

Positioning sebuah produk merupakan sebuah proposisi nilai (Panda, 2007: 258). Berdasarkan positioning yang dimiliki merek, calon konsumen dapat mengetahui dan mempersepsi asosiasi-asosiasi yang melekat pada sebuah merek. Asosiasi-asosiasi tersebut berkenaan dengan manfaat-manfaat yang diberikan merek jika dikonsumsi atau digunakan. Nilai muncul dari perhitungan konsumen mengenai manfaat yang diterima dan risiko yang merek hadapi dari pembelian atau penggunaan merek.

Komunikasi pemasaran berkaitan dengan pertukaran nilai yang saling menguntungkan antara produsen dengan konsumen (Varey, 2002: 4). Nilai bagi produsen umumnya adalah keuntungan finansial, selain juga agar merek produk dan perusahaan terangkat melalui tingginya penjualan dan kualitas produk. Sedangkan nilai bagi konsumen adalah solusi bagi masalah atau kebutuhannya. Proposisi nilai dalam positioning N219 ini dibentuk melalui tiga tahapan proses, yakni proses generatif, produktif, dan representatif.

Proses generatif mengkonstruksi pengetahuan dalam berbagai aktivitas yang ditujukan untuk memberikan solusi bagi masalah-masalah yang dimiliki baik oleh konsumen maupun perusahaan sebagai produsen (Varey, 2002: 80). Untuk dapat menyelesaikan masalah-masalah tersebut, PTDI perlu mengidentifikasinya melalui riset pasar.

Sebelum melakukan riset pasar, mesti diketahui terlebih dahulu siapa konsumen yang dituju. Dengan demikian, perusahaan dapat menawarkan solusi berdasarkan kompetensi yang mereka miliki dan kebutuhan yang mungkin dimiliki oleh segmen pasar sasaran. Yadi Mulyadi menjelaskan pasar sasaran N219 sebagai berikut:

"Segmentasi (pesawat N219) untuk daerah yang sejenis dengan Indonesia, yang memiliki kesamaan geografis dengan Indonesia, khususnya yang kepulauan. Bisa boleh di Afrika, di ASEAN, itu sangat cocok, karena itu diperuntukkan untuk daerah-daerah dengan ketinggian, untuk penerbangan-penerbangan perintis, yakni lapangan terbang yang tidak begitu lengkap... Jadi diperuntukkan khususnya untuk wilayah Asia dan Pasifik. Kalau Indonesia itu Indonesia Timur" (Wawancara narasumber, 5 Juni 2016)

Riset pasar yang dilakukan PTDI menunjukkan bahwa ada potensi pada pasar pesawat terbang kelas ringan. Ini ditunjukkan oleh berbagai faktor, seperti banyaknya penerbangan perintis yang belum terlayani dengan baik di Indonesia, jumlah bandara perintis dan airstrip yang semakin bertambah seiring bertumbuhnya kebutuhan akan penerbangan perintis, serta tingginya penggunaan pesawat Twin Otter model lama untuk melayani penerbangan-penerbangan ini, padahal model pesawat tersebut tidak lama lagi tidak diperbolehkan lagi untuk beroperasi di Indonesia.

Pengembangan produk N219 didasarkan pada data-data di lapangan mengenai kebutuhan konsumen, yakni bagaimana pesawat terbang perintis yang mereka inginkan. Selain itu PTDI juga menganalisa pesawat Twin Otter untuk dijadikan pembanding. Riset pasar menunjukkan dimulainya aktivitas pertukaran antara PTDI dan konsumennya, yang dimulai dari pertukaran informasi mengenai kebutuhan dan keinginan serta permasalahan yang dihadapi.

Riset pasar memberikan pengetahuanpengetahuan yang akan dioleh menjadi produk yang mengandung nilai. Riset pasar diperlukan dalam program ini, karena sebelumnya kegiatan pemasaran PTDI lebih banyak berfokus pada alat-alat militer, sedangkan kebutuhan militer dan sipil sangat berbeda. Kesuksesan sebuah program pemasaran bergantung pada kemampuan perusahaan dalam mengidentifikasi kebutuhan dan karakteristik pasar targetnya (Panda, 2007: 261). Peran riset pasar begitu penting bagi positioning N219 agar dapat mengetahui kebutuhan konsumen, dan menyesuaikan positioning dengan kebutuhan konsumen. Positioning dibentuk sebagai pengembangan produk yang dapat melayani secara spesifik kebutuhan dan harapan konsumen (Dibb dan Simkin, 1996: 18).

Pengolahan data riset tidak hanya dilakukan oleh PTDI saja, namun juga melibatkan Lapan sebagai instansi yang bekerjasama dengan PTDI dalam pengembangan proyek ini. Selain berperan dalam pengelolaan biaya, Lapan juga ikut serta dalam kegiatan research dan 
development pesawat N219. Jadi, mereka juga berkontribusi dalam menentukan teknologi yang digunakan untuk proyek ini. Peran Lapan tersebut dijelaskan Kerry Apriawan seperti berikut ini:

"Jadi N219 kan itu juga proyek pemerintah, itu kan butuh biaya besar juga kan untuk research and development-nya. Kan dulu beda, karena uang itu langsung ke Pak Habibie langsung ke PTDI, dipakai untuk program N250. Untuk investasi untuk biaya pembuatan pesawat itu pasti dari pemerintah, tapi kan waktu distop dananya, proyeknya ga jalan, utangnya jadi utang PTDI, bukan utang pemerintah. Jadi beban buat kita untuk N250 padahal proyeknya proyek pemerintah juga kan. Nah, ini konsep baru dari pemerintah supaya nantinya tidak terjadi hal yang sama di proyek N219. Ke keuangan PTDI-nya bagus jadi kita ada yang mengontrol. Itu Lapan sendiri. Lapan pun emang mengurus penerbangan juga, dulu mereka juga pernah buat pesawat untuk penerbangan kita di Indonesia. Untuk biaya riset dan development dari Lapan, kita sampai terbang perdana pun itu dari Lapan. Itu sekitar 500 miliar, pendanaan dari Lapan. Tapi kita karena diperiksa oleh BPK, Lapan yang mengontrol pengeluarannya" (Wawancara narasumber, 4 Juni 2016).

N219 diposisikan sebagai pesawat terbang kelas ringan generasi baru dengan tagline
"The New Generation of Light Class Aircraft." Positioning ini dibangun dari point of parity sebagai pesawat terbang kelas ringan dan point of difference sebagai sebuah pesawat generasi baru. Point of difference tersebut selain menunjukkan perbedaan generasi antara N219 dan Twin Otter, juga menyiratkan kesan modern pada pesawat N219 ini.

Kebutuhan konsumen terhadap produk pesawat terbang kelas ringan sebetulnya adalah kebutuhan fungsional. Kebutuhan fungsional adalah kebutuhan yang memotivasi pencarian produk yang mengatasi permasalahan yang sedang dihadapi, meredakan konflik, atau merestrukturisasi (Ghodeswar, 2008: 5). Umumnya konsumen pesawat terbang perusahaan atau instansi yang memang membutuhkan pesawat terbang sebagai alat transportasi, sehingga biasanya hanya bertujuan untuk pengadaan dan kurang mempertimbangkan aspek-aspek nilai lainnya. Keberadaan nilai yang ditambahkan kepada merek sebuah produk dapat memengaruhi keputusan pembelian konsumen terhadap produk.

Perangkat proposisi nilai N219 dimodifikasi berdasarkan pengalaman mereka dengan produk Twin Otter sebagai pesaingnya. Proposisi nilai dibentuk dari manfaat-manfaat fungsional, emosional dan ekspresi-diri. Manfaat fungsional N219 adalah keberadaan produk sebagai sebuah pesawat yang handal dalam menghadapi kondisi geografis yang ekstrim, karena mampu terbang rendah dengan

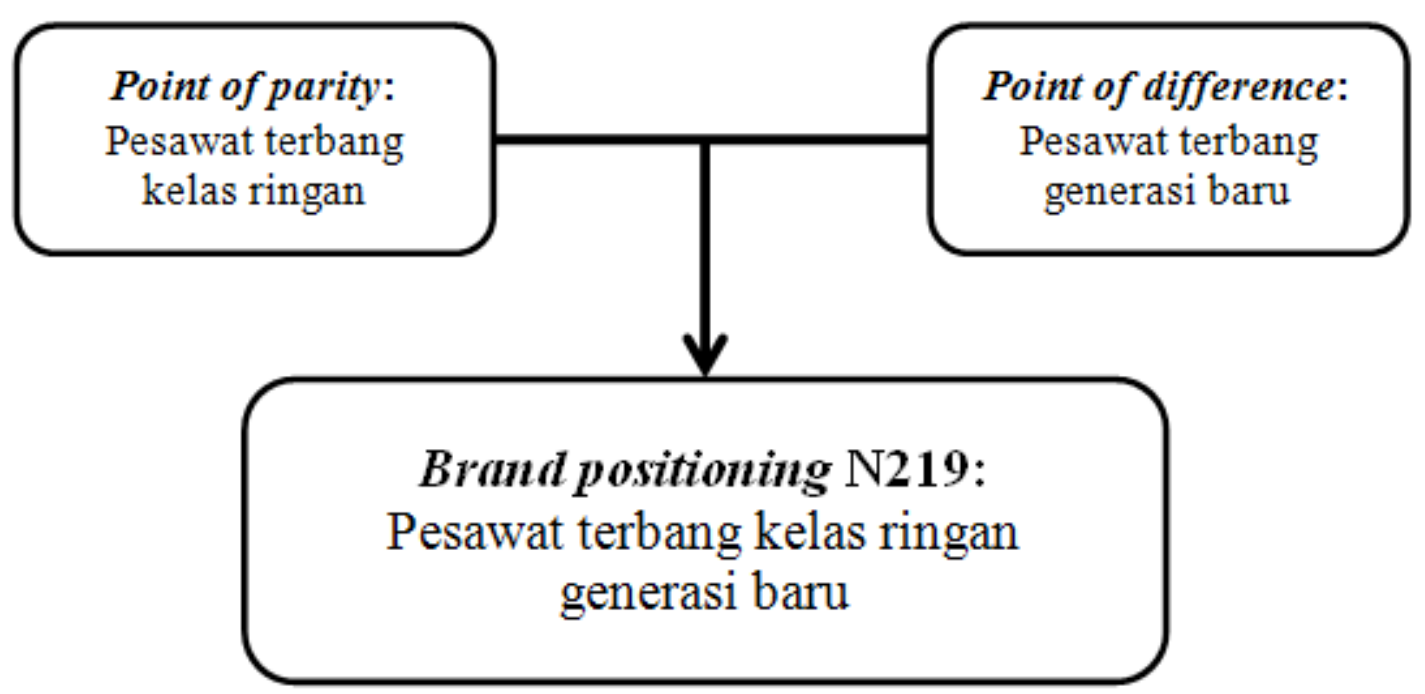

Sumber: Rangkuman Peneliti, 2016

Gambar 1 Pembentukan Brand Positioning N219 
kecepatan rendah; kokpit berteknologi digital yang mampu membantu pilot melewati kabut atau asap dengan tampilan layar tiga dimensi; sayap yang bisa mengangkut lebih banyak barang; bahkan kabin yang lebih luas dan tinggi sehingga penumpang tidak perlu menunduk saat berdiri di dalamnya; serta banyak lagi manfaat fungsional lainnya yang ditawarkan produk ini. Selain itu, manfaat lainnya adalah kebutuhan akan pesawat terbang atau penggantian pesawat yang sudah menua. Lebih lanjut, Yadi Mulyadi menjelaskan tentang manfaat fungsional pesawat ini sebagai berikut:

"N219 itu pesawat yang handal di lapanganlapangan terbang kecil dan antar pulau, dan di situasi yang ekstrim. Itu sebenarnya tagnya itu. Terus pesawat ini juga kita punya brand image-nya itu sebagai $h u b$ and-spoke. Jadi pesawat yang dipergunakan dari lapangan terbang utama ke lapangan terbang kecil. Jadi itu penyambung. Itu sebenarnya penempatannya, positioningnya itu yang menjadi target. Itu akan menjadikan saingan terhadap pesawatpesawat sekelas."

Manfaat emosional yang ditawarkan N219 adalah keberadaan pesawat ini sebagai pesawat terbang karya anak bangsa. Pesawat ini dikerjakan sepenuhnya oleh orang Indonesia tanpa adanya bantuan tenaga asing, dan kandungan lokal di pesawat ini juga sangat tinggi mencapai $60 \%$, dibantu dengan pemberdayaan industri lokal dalam pembuatan jok, kaca, dan sebagainya. Manfaat emosional yang diberikan adalah rasa bangga bagi konsumen Indonesia terhadap produk ini, bahwa Indonesia terbukti dapat membuat pesawat sendiri.

Manfaat ekspresi-diri untuk produk N219 ini juga berkaitan dengan keberadaan N219 sebagai pesawat terbang karya anak bangsa, sehingga menjadikan maskapai mereka sebagai maskapai yang mendukung produk Indonesia dan turut serta membangkitkan perindustrian pesawat terbang Tanah Air.

Manfaat emosional dan manfaat ekspresi diri muncul dari positioning N219 sebagai karya anak bangsa. Keunggulan paling utama pesawat N219 ini adalah dirancang dan dibuat oleh bangsa Indonesia untuk keperluan di Indonesia. Dengan demikian diharapkan pesawat ini dapat dengan tepat menjawab kebutuhan penerbangan perintis di Indonesia. Pesawat N219 dipilih oleh PTDI karena relatif lebih sederhana tapi fungsinya itu sesuai dengan kebutuhan Indonesia yang banyak pulaunya, kemudian banyak wilayah yang terpencil yang lahannya terbatas.

Tingkat kandungan lokal yang tinggi juga memberikan keuntungan bagi N219. Ini membuat PTDI lebih dipilih oleh konsumen dalam negeri dibandingkan dengan produkproduk luar negeri, pasar utama yang ingin dituju PTDI melalui produk ini. Adi Prastowo menjelaskannya seperti berikut ini:

"Tingkat kandungan lokal lebih tinggi, karena dibuat di PTDI kan. Terus harga. Kalau harga, sih, bersaing ya, relatif bisa lebih mahal lebih murah. Kemudian after sales service nya lebih mudah, karena di Indonesia. Terus dari Undang-Undang tadi, yg menyatakan harus membeli produk lokal yang tingkat kandungan lokalnya bisa lebih tinggi. Dari undang-undang kita dimenangkan" (Wawancara narasumber, 14 Juni 2016).

Pesawat N219 juga dikaitkan dengan kebangkitan industri penerbangan Indonesia. Kerry Apriawan menyebutkan bahwa:

"Iya pasti jadi kebangkitan industri penerbangan, karena terakhir kita bisa bikin, kaya CN235 itu kan masih 50-50 buatan Spanyol buatan Bandung. Tapi, kan, ga dari awal sampe akhir buatan sini, baru N250 dan sekarang N219."

Menurut Adi Prastowo, wacana tentang N219 sebagai lambang kebangkitan industri penerbangan Indonesia itu berkaitan dengan rasa nasionalisme.

"Kalau dihubungkan sama kebangkitan industri penerbangan, ruang lingkupnya itu nasional. Jadi itu hubungannya dengan nasionalisme. Misalnya tahun ini untuk hari kebangkitan teknologi itu yang akan diselenggarakan di Solo, tempatnya Jokowi. Nah di sana kita munculin semuanya, kebanggaan-kebanggaan yang ada unsur high tech-nya. Tadinya N219 juga mau first flight-nya 10 Agustus."

Dengan menghubungkan N219 dengan Hari Kebangkitan Teknologi Nasional, artinya ada upaya dari PTDI untuk memunculkan N219 sebagai sebuah momentum. Meskipun 
menggunakan teknologi yang sederhana, namun proyek N219 ini dilakukan sepenuhnya oleh orang Indonesia, mulai dari perancangan sampai perakitan bahkan hingga nanti penerbangan perdana, tanpa adanya bantuan technical assistant asing.

Proses produktif adalah upaya dari perusahaan untuk mengolah pengetahuan yang dimiliki untuk membuat produk atau proposisi nilai sebagai bagian dari penawaran yang dibuat untuk konsumen (Varey, 2002: 80). Dalam memproduksi pesawat yang sesuai dengan keperluan penerbangan perintis, setelah diperoleh data-data di lapangan, maka PTDI kemudian menganalisa dan mempelajari Twin Otter sebagai pedoman proyek N219. Pesawat diproduksi dengan memperhatikan pesan-pesan positioning yang telah ditetapkan.

Produksi N219 dilaksanakan sedemikian rupa karena adanya tujuan untuk menjadikan pesawat ini sebagai pesaing Twin Otter.

"Selain harganya lebih murah dari Twin Otter, teknologinya lebih baik dari Twin Otter, kenyamanan penumpangnya juga kita perhatiin. Itu sebenarnya salah satu strateginya untuk mengalahkan saingannya kita yakni si Twin Otter tadi. Itu bisa jadi yang menjual, kasarnya apa sih yang didagangin supaya laku gitu kan, mulai dari teknologi, sayap yang bisa menahan lebih besar, yang bisa manuver kecepatan rendah terbang rendah, dan harganya lebih murah. Itu sebagian dari kelebihan N219 itu" (Wawancara narasumber, 4 Juni 2016).

Proses representatif adalah proses menghubungkan manifestasi pengetahuan berupa produk melalui cara-cara di mana konsumen dapat menghubungkannya dengan sistem penciptaan nilai mereka. Proses ini dilakukan melalui implementasi komunikasi pemasaran yang terintegrasi menggunakan berbagai sarana komunikasi pemasaran.

Dalam tahap representatif ini, pesan positioning N219 tersebut disampaikan melalui berbagai sarana komunikasi pemasaran. Saranasarana tersebut antara lain pameran pemasaran, publisitas, dan pendekatan langsung. Pameran

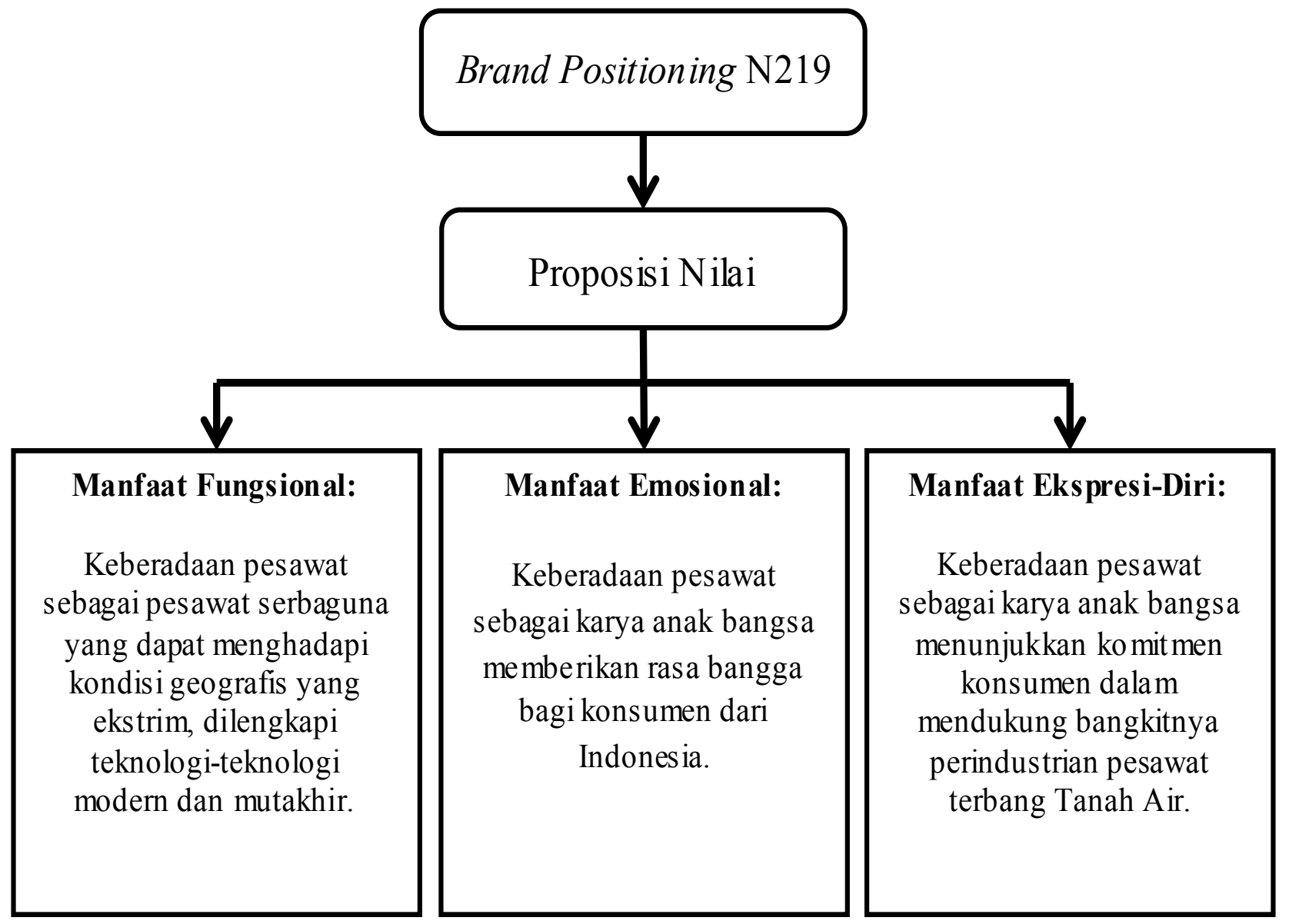

Sumber: Rangkuman Peneliti, 2016

Gambar 2 Hasil Proses Generatif (Brand Positioning dan Proposisi Nilai) 
pemasaran yang utama dilakukan PTDI adalah pameran bisnis (trade shows). Pameran bisnis merupakan sarana utama dalam memasarkan N219, yakni kenyataan bahwa pameran bisnis yang paling banyak digunakan. Karena merupakan tempat bertemunya produk dan konsumen secara langsung, maka keberadaan pameran ini menjadi tepat sasaran sehingga lebih efektif dibandingkan sarana lainnya. Strategi-strategi yang dilakukan di antaranya adalah dengan memberikan kesempatan bagi pengunjung mencoba simulator N219, menampilkan pesan Wonderful Indonesia bekerjasama dengan Kementerian Pariwisata, dan sebagainya. Mengenai penggunaan simulator di pameran N219, Adi Prastowo menjelaskannya seperti berikut ini:

"Biasanya kalau pameran biasanya cukup atraktif. Jadi kita tampilkan simulator, terus para pengunjung kita kasih kesempatan untuk gunain simulator, supaya tau gimana sih ini pesawat, nyetir pesawat kaya gimana sih, pemandangannya seperti apa. Kalau simulator kan nyaris seperti aslinya, walaupun itu hanya visual tapi orang pasti punya kesan tersendiri setelah nyobain take off landingnya N219. Nah di situ kita kasih reward juga untuk pengunjung yang bisa take off landing dengan selamat, kita kasih reward berupa merchandise. Orang-orang itu pasti ga akan lupa, pernah ngendaliin dan pernah dapat sovenir. Daya tariknya seperti itu sepertinya, strategi-strateginya

Lumayan pengunjungnya cukup antusias. Jadi kita bawa simulator, kita bawa juga product display-nya. Terus kita putar juga film tentang N219, jadi mereka punya bayangan. Begitu datang, lihat posterposter N219. Pesawatnya kaya gini, gambarnya kaya gini, terus dia lihat video cara pembuatannya, semuanya kan divideo-in tuh, abis itu dia nyobain. Dari situ orang pasti punya interest, punya rasa ingin tahu yang lebih tentang N219. Langsung cobain simulatornya.

Kemudian dari situ setelah dia coba simulator, mungkin dia pengen tahu lebih dalam spec teknis, kita udah sediain di situ yang namanya booklet. Booklet itu terjemahan dari brosur, kalo brosur kan cuma selembar ya, secara umum. Nah itu ada booklet-nya, jadi orang pengen tahu lebih dalam dimensinya seperti apa, kemampuannya, jarak tempuhnya, segala macamnya ada, dari situlah" (Wawancara narasumber, 14 Juni 2016).

Sedangkan kerja sama PTDI dan Kementerian Pariwisata dijelaskan Kerry Apriawan seperti berikut ini:

"Di Singapura Airshow pun kita kerjasamanya sama Kementerian Pariwisata. Kenapa dengan kementerian pariwisata? Pertama, di booth-nya PTDI kita bisa buat kerjasama dengan Kementerian Pariwisata itu ada Puteri Pariwisatanya. Sekarang orang di pameran segitu banyak supaya menarik kan bukan orang-orang yang sudah tua yang dipajang di sana kan, kita kerjasama dengan Menteri Pariwisiata itu ada Puteri Pariwisatanya dua orang untuk menerima tamu-tamu. Nah itu dibilang cukup efektif karena banyak yang datang, pertama bukan mau lihat PTDI-nya tapi mau lihat Puteri Pariwisatanya, karena kan mereka pakai baju adat kita juga. Jadi yang ngedatengin Puteri Pariwisatanya, kita ajak pengunjung ke booth-nya PTDI, isi buku tamu, lalu mau nggak mau mereka menanyakan produk PTDI. Itu kita kerjasama dengan Menteri Pariwisata.

Selain itu juga di brosur dan di booth-nya juga kita ada kerjasama sama Menteri Pariwisata dalam pencantuman Wonderful Indonesia-nya, jadi N219-nya kita pajangin di brosur tapi background-nya itu tentang objek wisata di Indonesia, kaya Raja Ampat. Itu kita sudah ada MoU nya dengan Kementerian Pariwisata. Jadi nanti setiap pameran di luar, selain mempromosikan objek wisata Indonesia, pesawat PTDI-nya N219 kita promosikan. Khususnya N219. Begitupun nanti Kementerian Pariwisata di luar negeri ada pameran, sama mereka juga akan promosikan pesawatnya PTDI khususnya N219" (Wawancara narasumber, 4 Juni 2016).

Pendekatan langsung adalah pemasaran melalui tatap muka dengan maskapaimaskapai perintis dan pemerintah daerah untuk menawarkan produk N219. Pendekatan ini di dalam negeri dilakukan dengan memperkenalkan N219 pada setiap kabupaten, provinsi, kepada pemerintah maupun maskapai penerbangan. Pendekatan ini dilakukan 
baik melalui kunjungan langsung maupun pengadaan gathering. Sedangkan untuk pemasaran luar negeri, PTDI menggunakan jasa agen pemasaran, serta bantuan dari duta besar-duta besar Indonesia di luar negeri yang menawarkan produk-produk PTDI di negara tempatnya bertugas.

Publisitas merupakan kegiatan memunculkan informasi untuk diketahui publik. Publisitas berbeda dengan bentuk komunikasi pemasaran lainnya karena di sini identitas perusahaan sebagai sponsor tidak ditunjukkan (Varey, 2002: 176). Kegiatan publisitas ditujukan untuk menyebarluaskan positioning mereka ke khalayak dan juga konsumen potensial. Untuk itu, PTDI telah mulai bekerjasama dengan Metro TV untuk peliputan acara penerbangan perdana N219, juga aktivitas sebelum dan sesudah acaranya. Metro TV juga mengundang Direktur Utama PTDI Budi Santoso untuk hadir di Economic Challenge pada tanggal 24 Mei 2016 sebagai salah satu kerja sama dalam publisitas. Mediamedia massa lainnya juga turut meliput, seiring tingginya animo masyarakat terhadap pesawat terbang karya anak bangsa PTDI. Ini sesuai dengan pernyataan Harry Harjoyo berikut ini:

"Untuk N219 ini media itu banyak yang ngejer kita sebenarnya, karena di penerbangan sendiri terutama yang paket lengkap, yang mulai dari nol ngedesain, ngerakit, ngebuat sampe ngereparasi pun kita ada di sini, bisa dibilang PTDI itu perusahaan paket lengkap. Di asia juga ada perusahaan penerbangan, tapi itu hanya reparasi bukan ngebikin. Dari situ media pun merasa memiliki kebanggaan terhadap produk PTDI karena ini hasil karya kita, N219 itu murni orang Indonesia yang bikin. Brand positioning-nya sendiri N219 ini adalah karya Indonesia, media juga jadi makin tertarik. Jadi tanpa perlu gembargembor segala macem, kita cuma ngundang media doang, N219 mau terbang perdana, langsung rame. Kaya kemaren roll out-nya sendiri sampai dari Jepang, Kuwait, pada datang ke sini medianya. Kita ga ngundang mereka tapi itu jadi daya tarik buat mereka, Karena N219 sendiri karya Indonesia, industri dirgantaranya sendiri bakal hidup dari situ."

Positioning melalui publisitas ini bisa jadi yang paling efektif dibandingkan dengan sarana komunikasi pemasaran lainnya. Ini dikarenakan kredibilitas pesan yang disampaikan pada khalayak dan konsumen potensial lebih tinggi karena disampaikan oleh media massa. Informasi tersebut lebih berkesan lepas dari unsur komersial karena pihak sponsor tidak disebutkan.

Hubungan tiga proses tersebut, yakni generatif, produktif dan representatif dalam penciptaan nilai digambarkan oleh gambar 3. Model pada gambar 3 menggambarkan proses terpisah dan bukan proses yang saling bersilangan. Ini didasari pada temuan di PTDI bahwa ketiga proses tersebut dilaksanakan secara bertahap dan tidak saling tumpang tindih. Hubungan satu proses ke proses lainnya digambarkan dua arah, karena walaupun merupakan proses yang bertahap dan berurutan, proses bisa berbalik arah dan berulang dikarenakan adanya penekanan ulang dalam proses.

Jika model ini diintegrasikan dalam pertukaran nilai, yang dikaitkan dengan model jaringan sosial dari Wikstroem dan Normann (dalam Varey, 2002: 82), maka komunikasi pemasaran dapat digambarkan oleh gambar 4. Model pada gambar 4 menunjukkan terjadinya pertukaran antara PTDI dan konsumen yang berbasisi nilai. Nilai yang ditawarkan PTDI berbentuk produk yang mengandung nilai-nilai dan disampaikan melalui pesan positioning. Pembentukan positioning tidak hanya mempertimbangkan identitas perusahaan saja, namun harus pula memperhatikan kebutuhan dan permasalahan konsumen agar dapat memberikan nilai guna yang tepat bagi konsumen yang membutuhkannya.

Komunikasi yang terjadi antara PTDI dan konsumen juga terjadi dalam dua bentuk, yakni komunikasi satu tahap dan komunikasi dua tahap. Komunikasi satu tahap terjadi saat PTDI pertukaran nilai terjadi pada aktivitas pameran bisnis dan pendekatan langsung. Melalui aktivitas tersebut PTDI dapat berkomunikasi secara langsung dan mendapatkan umpan balik secara langsung. Komunikasi satu Sedangkan melalui publisitas di media massa bisa jadi berbentuk satu tahap maupun dua tahap. Hal ini dikarenakan publisitas di media massa dapat menjangkau penerima pesan yang lebih luas sehingga baik konsumen maupun pemegang kepentingan lain dari konsumen bisa menerima 


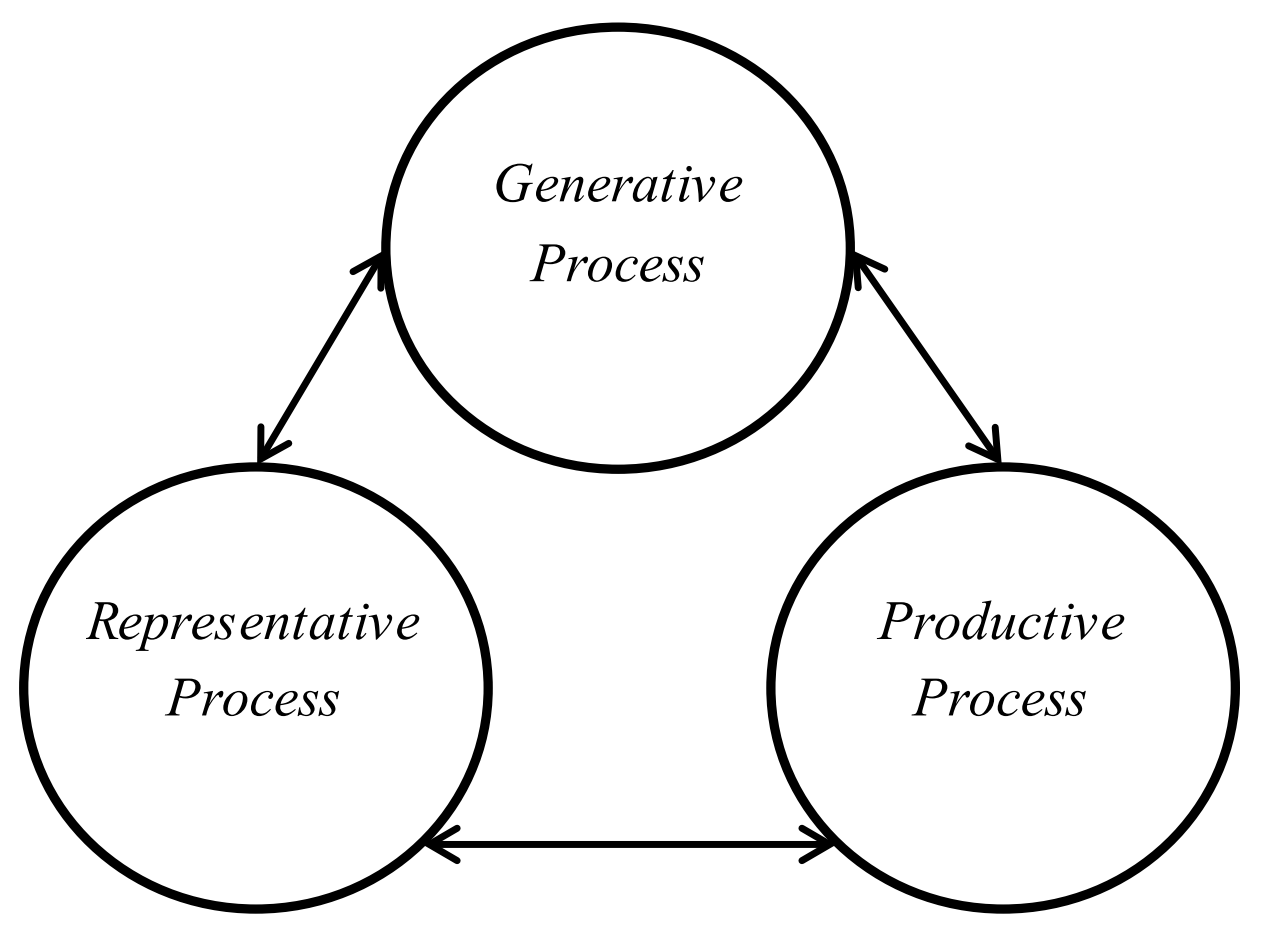

Sumber: Varey, Marketing Communication: Principles and Practice, 2002: 81, dengan modifikasi penulis, 2016 Gambar 3 Sistem Pemrosesan Pengetahuan Pencipta Nilai

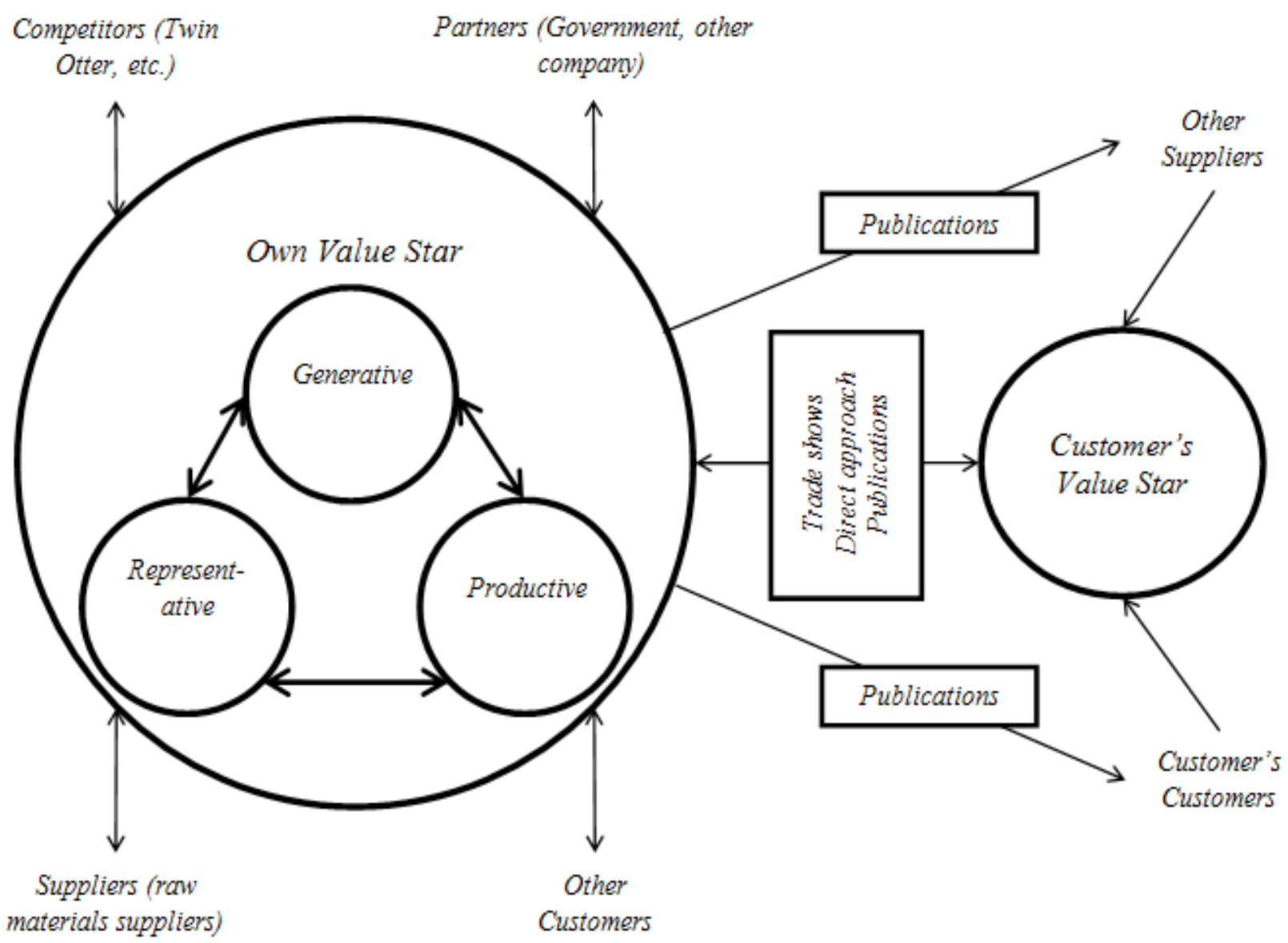

Sumber: Berdasarkan model Varey (2002: 82) dengan modifikasi penulis, 2016

Gambar 4 Jaringan Sosial dalam Pemasaran N219 
Div. Penelitian dan Div. Promosi dan

Analisa Pasar

Komunikasi Pemasaran

Div. Jaringan dan

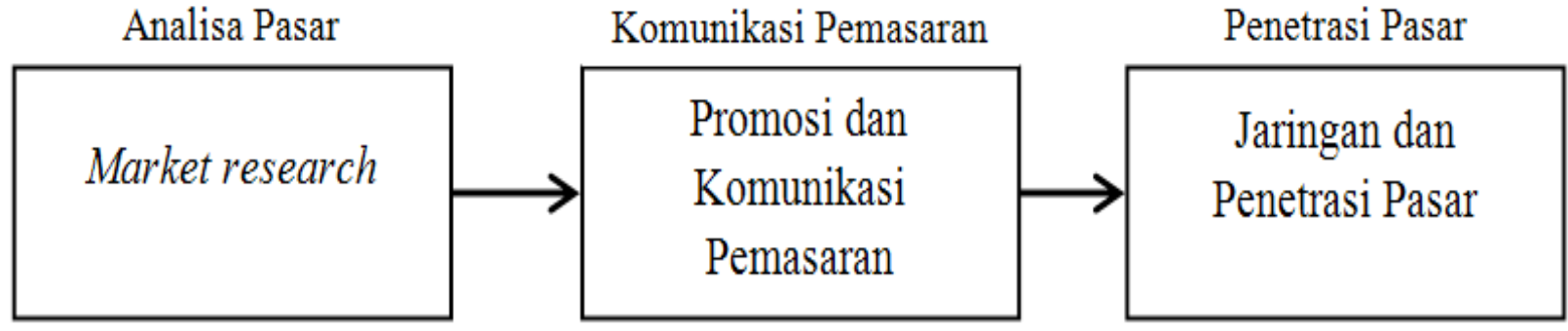

Sumber: Dokumen Divisi Promosi dan Komunikasi Pemasaran, 2016

\section{Gambar 5 Alur Kerja Fungsi Komunikasi Pemasaran di PTDI}

pesan tersebut.

Dalam menjalankan tugasnya, fungsi pemasaran di PTDI terdiri dari tiga tahap yang masing-masing dijalankan oleh divisi yang berbeda di dalam Direktorat Niaga dan Restrukturisasi. Ketiga fungsi tersebut antara lain market research yang dijalankan Divisi Penelitian dan Analisa Pasar, komunikasi pemasaran dan promosi yang dijalankan Divisi Promosi dan Komunikasi Pemasaran, dan penetrasi pasar dan pembangunan jaringan yang dilaksanakan oleh Divisi Jaringan dan Penetrasi Pasar.

Aktivitas pemasaran yang dilakukan dalam kegiatan promosi dan komunikasi pemasaran didasari pada data-data hasil penelitian pasar yang dilakukan Div. Penelitian dan Analisa Pasar. Adanya data-data ini memberikan pedoman mengenai perumusan strategi dan taktik pemasaran yang akan dilakukan. Strategi dan taktik pemasaran dirancang sepenuhnya oleh Div. Promosi dan Komunikasi Pemasaran, dengan persetujuan Direktorat Niaga dan Restrukturisasi dan Direktur Utama.

Respons yang didapat dari aktivitas pemasaran kemudian diteruskan ke Divisi Jaringan dan Penetrasi Pasar. Tugas utama divisi ini adalah untuk mengarahkan ketertarikan menjadi pembelian, dengan memberikan gambaran mengenai pesawat yang diminati konsumen potensial. Tidak berhenti di situ, divisi ini juga bertugas untuk menjalin hubungan baik dengan konsumen-konsumen dengan membangun jaringan sosial.

Sedangkan untuk kelompok-kelompok stakeholder lainnya, tanggung jawab untuk menjalin hubungan dengan mereka, seperti media massa, instansi pemerintah, serta masyarakat sekitar, adalah milik Divisi Humas. Hubungan tersebut dibentuk untuk menjaga nama baik perusahaan di mata para stakeholder.

Harry Harjoyo menjelaskannya bagaimana peran Divisi Humas terhadap pemasaran produk seperti berikut ini:

"Tugasnya humas itu sebenarnya adalah untuk menjaga gimana caranya supaya PTDI itu tetap baik. Kalau PTDI dipandang baik sama orang, kan pasti produknya juga ikut keangkat. Media-media nanti jadi berdatangan, nanti dampaknya kan ke penjualan juga" (Wawancara narasumber, 4 Juni 2016).

Di sini Divisi Humas juga berkontribusi dalam pemasaran N219, yakni dengan menjalin hubungan dengan media massa. Dengan menjaga pemberitaan positif di media massa, maka berita yang positif mengenai produk N219 akan diterima konsumen potensial dan menimbulkan ketertarikan pada konsumen tersebut.

\section{SIMPULAN}

Berdasarkan kajian pasar, pasar pesawat terbang kelas ringan merupakan pasar yang potensial yang dihuni market leader Twin Otter, terakhir diproduksi pada 1988. Disebut sebagai pasar potensial dikarenakan adanya regulasi yang melarang pengoperasian pesawat yang telah berusia 30 tahun di Indonesia. N219 dimaksudkan sebagai produk pengganti sehingga perlu diposisikan sebagai produk yang memiliki karakteristik sama namun lebih modern. PTDI tidak pernah lagi memproduksi pesawat sendiri setelah N250 pada tahun 1997 dan lebih banyak memproduksi produk alutsista dibandingkan untuk keperluan sipil. Untuk masuk di pasar ini, PTDI memerlukan positioning yang tepat agar mudah diingat 
oleh konsumen potensial dan memberikan keuntungan kompetitif. Selain itu, fokus dari positioning tersebut haruslah di Indonesia terlebih dahulu karena pasar Indonesia untuk penerbangan perintis sudah cukup besar untuk kemudian masuk ke pasar internasional.

Brand positioning PTDI disusun berdasarkan proses penciptaannilai, yakniproses generatif, produktif dan representatif. Proses generatif melibatkan riset pasar, penentuan pernyataan posisi pasar, serta penentuan manfaat-manfaat fungsional, emosional, dan ekspresi-diri N219. Proses produktif merupakan proses pengolahan pengetahuan pada proses generatif menjadi produk yang mengandung nilai. Proses representatif melibatkan aktivitas penyampaian pesan positioning N219 pada konsumen potensial dan khalayak umum melalui pameran pemasaran, publisitas, dan pendekatan langsung.

Komunikasi pemasaran yang dilakukan PTDI untuk N219 bersifat B2B. Komunikasi pemasaran tersebut merupakan aktivitas pertukaran nilai yang saling menguntungkan antara PTDI dan konsumennya, dengan mengidentifikasi kebutuhan konsumen dan mengubahnya menjadi penawaran produk yang mengandung nilai. Pertukaran dilakukan atas dasar aturan timbal-balik, rasionalitas, dan konsistensi status dari aturan pertukaran teori pertukaran sosial.

Peneliti juga memberikan beberapa saran baik yang bersifat teoritis maupun praktis. Saran teoretis untuk penelitian ini di antaranya adalah penelaahan proses penciptaan nilai pada konsumen. Penelitian ini berupaya menjelaskan komunikasi pemasaran sebagai pertukaran nilai antara produsen dan konsumen dalam transaksi B2B. Penciptaan nilai pada produsen ditunjukkan melalui proses generatif, produktif, dan representatif. Namun, proses tersebut tidak cocok digunakan untuk menjelaskan penciptaan nilai pada pihak konsumen. Ini memberikan ruang bagi penelitian selanjutnya untuk mengetahui bagaimana konsumen transaksi B2B membentuk nilai yang mereka tawarkan pada produsen. Selain itu, menarik juga untuk diteliti bagaiaman hubungan proses generatif, produktif, dan representatif yang terjadi dalam penciptaan nilai di sebuah perusahaan. Hubungan ketiganya dapat dijadikan fokus pada penelitian selanjutnya, untuk membentuk model yang lebih tepat untuk penggambaran yang lebih universal.

Sedangkan saran praktis berdasarkan penelitian yang telah dijalankan adalah bahawa perlu adanya koordinasi yang lebih baik antara fungsi Humas dan Komunikasi Pemasaran, di dalam perusahaan karena keduanya merupakan alat utama perusahaan untuk berkomunikasi dengan pihak eksternal perusahaan. Koordinasi ini bertujuan agar informasi yang disampaikan bisa lebih selaras dan konsisten, serta sesuai dengan asas-asas yang dipegang perusahaan. Kemudian, perlu dieksplorasi saranasarana komunikasi pemasaran baru sebagai alternatif kunjungan langsung ke perusahaanperusahaan dalam pemasaran tatap muka, yang membutuhkan cukup banyak biaya dan waktu. Misalnya, dengan menempatkan lebih banyak perwakilan pemasaran (marketing representative) di daerah-daerah, dan sebagainya.

\section{DAFTAR PUSTAKA}

Dibb, S. \& Lyndon, S. (1996). The market segmentation workbook: target marketing for marketing managers. London: Routledge.

Ghodeswar, B. M. (2008). Building brand identity in competitive markets: a conceptual model. Journal of Product \& Brand Management, Vol. 17 No. 1 hal 4-12. Bingley: Emerald.

Hartoyo, N. M. \& Supriadi, D. (2015). Aktivisme sosial melalui penggunaan media sosial: studi kasus asosiasi ibu menyusui indonesia (aimi). Jurnal Kajian Komunikasi Vol. 3 No. 1 Hal. 1-11. Jatinangor: Fikom Unpad

Isnaini, S. (2009). Implementasi komunikasi pemasaran terpadu sebagai penyampai pesan promosi usaha kecil menengah (ukm) di indonesia. Masyarakat, Kebudayaan Dan Politik, 22(4), 324-332.

Komala, L., Novianti, E., \& Subekti, P. (2014). Strategi pemilihan media promosi kesehatan dalam penanggulangan hiv/aids di kabupaten garut. Acta DiurnA, 10(2), 34-43.

Limakrisna, N. (2008). Pengaruh komunikasi pemasaran dan kerelasian nasabah terhadap loyalitas nasabah. Jurnal Ekonomi Bisnis, 13(7), 68-79.

Panda, T. K. (2007). Marketing management: text and cases (second edition). New Delhi: 
Excel Books.

Varey, R. J. (2002). Marketing communication: principles and practice. Abingdon: Psychology Press.

Yin, R. K. (2003). Case study research, design and methods, 3rd edition. London: SAGE Publications.

. (2007). Qualitative research from start to finish. New York: The Guilford Press. 